\title{
Astonia (Alismataceae), a new genus for Australia
}

\author{
S.W.L. Jacobs
}

\begin{abstract}
Jacobs, S.W.L. (Royal Botanic Gardens, Sydney, Australia, 2000) 1997. Astonia (Alismataceae), a new genus for Australia. Telopea 7(2): 139-141. A new genus, Astonia, is described for the species formerly known as Limnophyton australiense H.I. Aston, and the new combination Astonia australiensis (Aston) S.W.L. Jacobs provided. The differences between related genera are discussed and a key provided to these and other genera in the family growing in Australia.
\end{abstract}

\section{Introduction}

When Aston (1987) described Limnophyton australiense she noted that it differed from other members of that genus in two important fruit characters, namely the presence of large spines and the absence of air canals (Limnophyton fruit are spineless and have lateral air canals). After examining the plants in the field there are several more characters that are not clearly obvious on preserved specimens. Firstly the bracts in the inflorescence are a deep maroon, as are the stamens, and the petals a creamy-yellow, some with a greenish tinge (Limnophyton has green bracts, white/yellow stamens and white petals). Secondly, the fruits of the Australian species are very much larger than those of any of the other species (11-12 $\times 8-9 \mathrm{~mm}$ vs $4-8 \times 3-4 \mathrm{~mm})$. Thirdly, the Australian species appears to have a unique flowering developmental sequence. As the lower whorl of bisexual or female flowers develops, the pedicels thicken and elongate geotropically, and the peduncle bends towards the water surface. When the fruit (nutlets) make contact with the water the remainder of the developing inflorescence containing the male flowers grows upwards or antigeotropically, leaving the developing nutlets in the water where they gradually separate and float away, the peduncle maintaining its curve. This developmental sequence has not been reported from any other species in the family and, coupled with the other characters above, warrants this species being placed in a genus of its own.

Haggard and Tiffney (1997) have reviewed the fruit types of the Alismataceae and their Table 1 provides a means of comparing the fruits of the extant genera. There is one deficiency in the table with a lack of any reference to spines on the fruit, a problem that seems to have led them to mistakenly list Caldesia acanthocarpa (F. Muell.) Buch. as a synonym of C. oligococca (F. Muell.) Buch. From the description of their C. acanthocarpa specimens they were looking at another species. Astonia, using the criteria in their Table 1, has fruiting carpels that:

(i) are elliptic in cross-section

(ii) are obovate laterally

(iii) are dorsally 3-ridged

(iv) have a chartaceous exocarp and a thick endocarp

(v) have no glands 
(vi) have a ventral style

(vii) have no lateral air chambers

(viii) are indehiscent

(ix) are wingless, and

(x) have one ovule.

In addition they have 4-6 robust spines to $6 \mathrm{~mm}$ long.

From those fruit characters on the list, Astonia only really differs from Limnophyton in the lack of lateral air chambers. There are other characters not on the list, as discussed, that also need to be considered when assessing relationships.

Astonia is most closely related to Limnophyton and Sagittaria. All three are monoecious with polymorphic pedicellate flowers. Sagittaria has numerous non-spinescent carpels arranged spirally on an elongated receptacle and an indefinite ( $>7)$ number of stamens. Although the fruiting pedicels of some species of Sagittaria thicken and recurve, no species are recorded as having a flowering system similar to Astonia australiensis.

The related genera and other Australian genera in the family Alismataceae can be distinguished with the following key:

1 Carpels in several whorls, apparently spirally arranged; flowers bisexual or unisexual

*arpels in 1 whorl; flowers bisexual

2 All flowers bisexual

Echinodorus

2* Lower flowers female or bisexual, upper flowers male 3

3 Nutlets numerous, flattened, spines usually absent, if present then $<2 \mathrm{~mm}$ long ... Sagittaria

$3^{*}$ Nutlets few, swollen, spines to $5 \mathrm{~mm}$ long or absent 4

4 Nutlets without spines, with lateral air canals; bracts green Limnophyton

$4^{*}$ Nutlets with spines to $5 \mathrm{~mm}$ long, without lateral air canals; bracts maroon

Astonia

5 Carpels more or less triangular with a long beak, united along a central axis

Damasonium

$5^{*}$ Carpels rounded on the back, not triangular, not united along central axis, often closely packed 6

6 Nutlets flattened, when mature forming a circular or rounded-triangular whorl ......

Alisma

$6^{*}$ Nutlets subglobose, when mature forming a loose aggregation

Caldesia

Astonia S.W.L. Jacobs, gen. nov.

Affinis Limnophyti sed nuculis spinosis, sine canalibus pneumaticis; bracteis staminibusque marroninis; petalis cremicoloribus; pedicellis fructificantibus spinsescentibus elongatis geotropis differt.

Aquatics with emergent leaves and inflorescences. Juvenile leaves linear, submerged; mature leaves with sagittate blades; apex obtuse. Inflorescence with up to 8 whorls of 
flowers, the lower 1(-2) whorl(s) bisexual with either bisexual or a mixture of female and bisexual flowers, sometimes with male flowers as well; upper whorls of male flowers; branches and pedicels bracteate, the bracts deeply coloured (maroon); lower bisexual whorl(s) opening and maturing first, the peduncle then bending towards the water until the nutlets contact the water surface, the tip of the inflorescence (with the opening male flowers) then turning upwards. Fruiting pedicels at first reflexing then thickening and elongating geotropically. Sepals 3, green. Petals 3, cream or greenish, constricted at the base. Stamens 6, coloured (maroon). Carpels 5-15; nutlets crowded, spinescent when mature, lateral air chambers absent. One species endemic to NE Queensland.

Astonia australiensis (Aston) S.W.L. Jacobs, comb. nov.

Basionym: Limnophyton australiense H.I. Aston Muelleria 6: 311-313 (1987).

Type: Queensland: Cook: $38 \mathrm{~km}$ from Wakooka on the track to Bathurst Bay and Cape

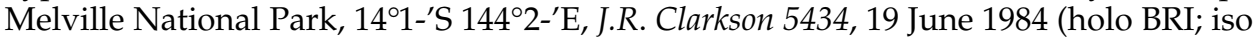
BRI, K, MEL, QRS; also spirit collections BRI, MEL).

Cape York Peninsula, north Queensland. Grows in shallow freshwater lagoons and waterholes in lowland areas.

The generic name is to honour Helen Aston who first described the species, in recognition of her distinguished record in studies of Australian aquatic plants.

\section{Acknowledgments}

I thank Karen Wilson for providing the Latin diagnosis, John Clarkson for enabling me to see the species in the field, and John Conran for drawing my attention to recentlypublished literature.

\section{References}

Aston, H.I. (1987) Limnophyton australiense sp. nov. (Alismataceae): a new generic record for Australia. Muelleria 6: 311-316.

Haggard, K.K. \& Tiffney, H. (1997) The flora of the Early Miocene Brandon Lignite, Vermont, USA. VIII. Caldesia (Alismataceae). American Journal of Botany 84: 239-252.

\section{Manuscript received 10 December 1996 Manuscript accepted 15 April 1997}


http://dx.doi.org/10.7751/telopea19971004 